\title{
SCIENCE FOR \\ A SUSTAINABLE \\ FUTURE
}

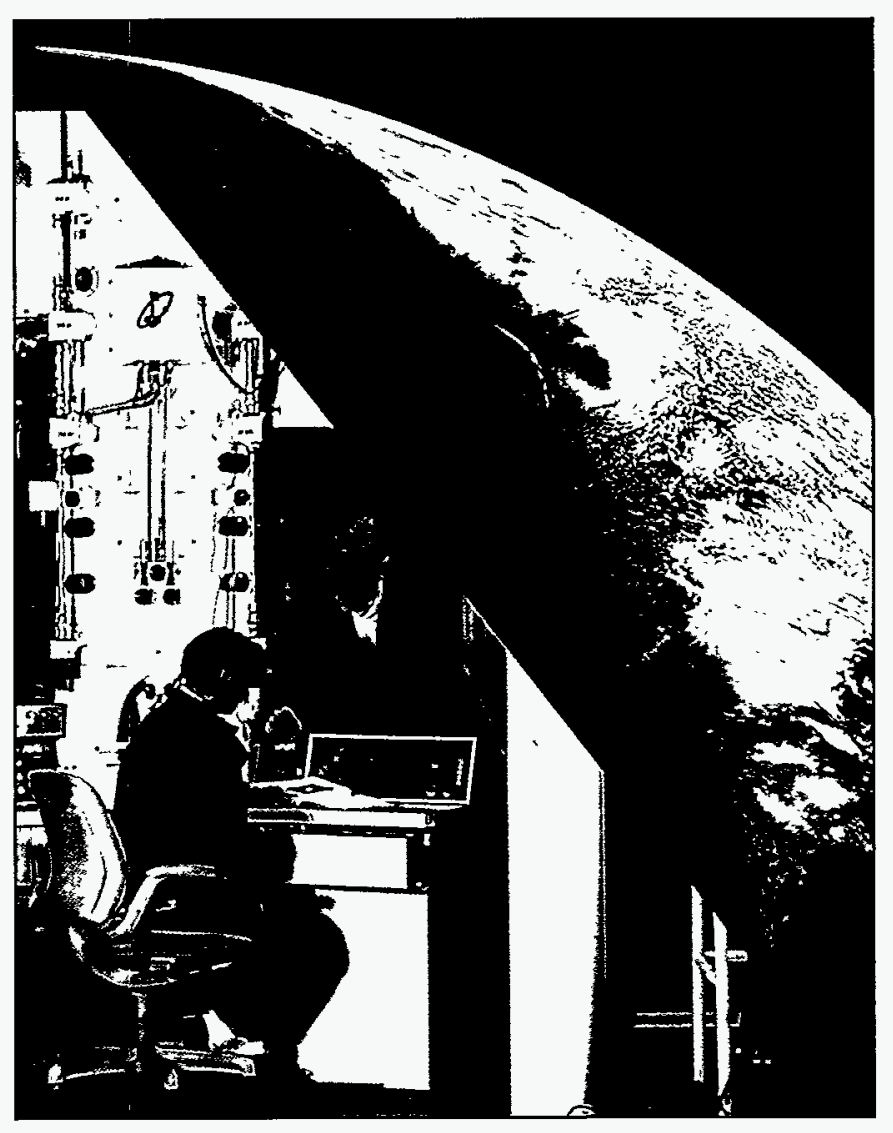

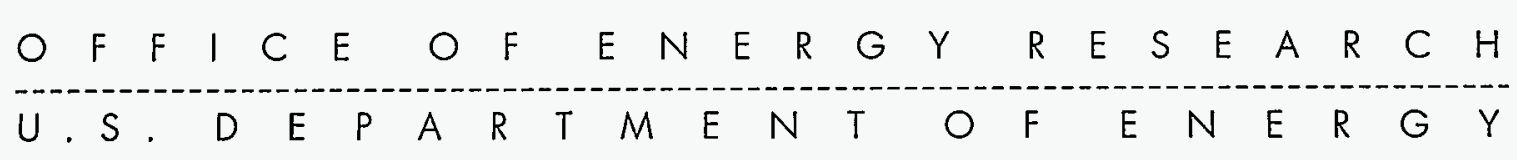




\section{DISCLAIMER}

Portions of this document may be illegible in electronic image products. Images are produced from the best available original document. 
A Sustainable future-science at the Core

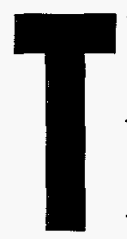

he vision of President Clinton's plan, Technology for a Sustainable Future, is to promote industrial development and economic expansion for all nations while improving and sustaining our environment. Advanced technology plays a crucial role in achieving this goal.

Science funded by the Department of Energy (DOE) provides the knowledge needed to create such technology, forming vital partnerships with industry to speed the process by which knowledge is converted into goods and services. The DOE funds more than $\$ 6$ billion in science and technology programs in a broad nexus that encompasses basic energy science, high-energy and nuclear physics, fusion energy, health and environmental research, and applied mathematical and computing science. This science is carried out in a network of universities and national laboratories spanning the nation. Interwoven with this scientific research are extensive programs in technology transfer in which the emphasis is on creating partnerships with American industry to solve national energy and technology needs.

Structured in a variety of ways to accomodate the needs of small companies as well as large corporations, these partnerships will help to accelerate the development and diffusion of environmental technology across the globe, resulting in more jobs, a cleaner environment, and a higher standard of living for ourselves and the generations that follow.

\section{DISTRIBUTION OF THIS DOCUMENT IS UNLIMITED}

\section{DISCLAIMER}

This report was prepared as an account of work sponsored by an agency of the United States Government. Neither the United States Government nor any agency thereof, nor any of their employees, makes any warranty, express or implied, or assumes any legal liability or responsibility for the accuracy, completeness, or usefulness of any information, apparatus, product, or process disclosed, or represents that its use would not infringe privately owned rights. Reference herein to any specific commercial product, process, or service by trade name, trademark, manufacturer, or otherwise does not necessarily constitute or imply its endorsement, recommendation, or favoring by the United States Government or any agency thereof. The views and opinions of authors expressed herein do not necessarily state or reflect those of the United States Government or any agency thereof.

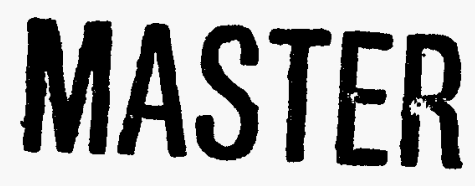




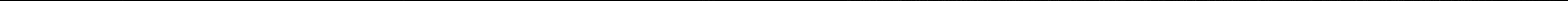




\section{The machines and}

instruments deployed

at DOE are as richly

varied as the myster-

\section{ies they were}

designed to explore.

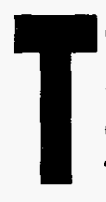

o solve any equation, you must fully understand its components. In the

Technology for a Sustainable Future equation, this means understanding the physical nature of the world in which we live - the overarching goal of the basic energy science, and the high-energy and nuclear physics programs.

- This understanding starts at the most basic level, the fundamental particles, such as quarks, that are the building blocks of atoms. It continues up the physical scale to where atoms combine to form the materials upon which our industrial capabilities depend, and where molecules such as proteins combine to form living cells.

- The scientific search for understanding also extends to the macroworld - to human health and the global environment, and to the secrets of the universe of which we are all a part.
- The machines and instruments deployed at DOE are as richly varied as the mysteries they were designed to explore. Particle accelerators and detector systems that enable scientists to study and manipulate atomic and subatomic bits of matter; microscopes that reveal the structural arrangement of atoms inside and on the all-important surfaces of organic and inorganic substances; imaging and monitoring devices that can record everything from the cognitive activity of the human brain to the movements of the earth below the planet surface and the air above; and advanced computers and high-speed networks for creating, managing, storing, and disseminating the knowledge that research acquires: This is but a sampler of the facilities available only at DOE's national laboratories.

- Many of these facilities are not only available to staff scientists, but are open to qualified users

from other federal agencies, from the nation's universities (which adds to the valuable educational component of the national laboratories) and from American industry. The capabilities and availability of the national user facilities, in combination with the various research partnerships, will help American industry join the national laboratories as participants and vital contributors to the goals of Technology for a Sustainable Future.

- This contribution will follow as a natural outgrowth of the Office of Energy Research's traditional leadership role in the funding of energy and environmental research, and will focus on the critical areas of clean manufacturing, energy efficiency, renewable sources of energy, and the quality of life.

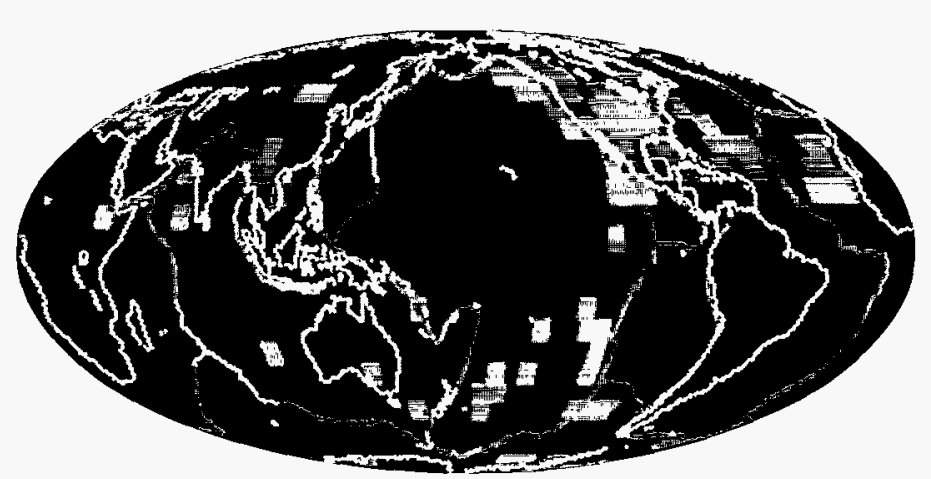



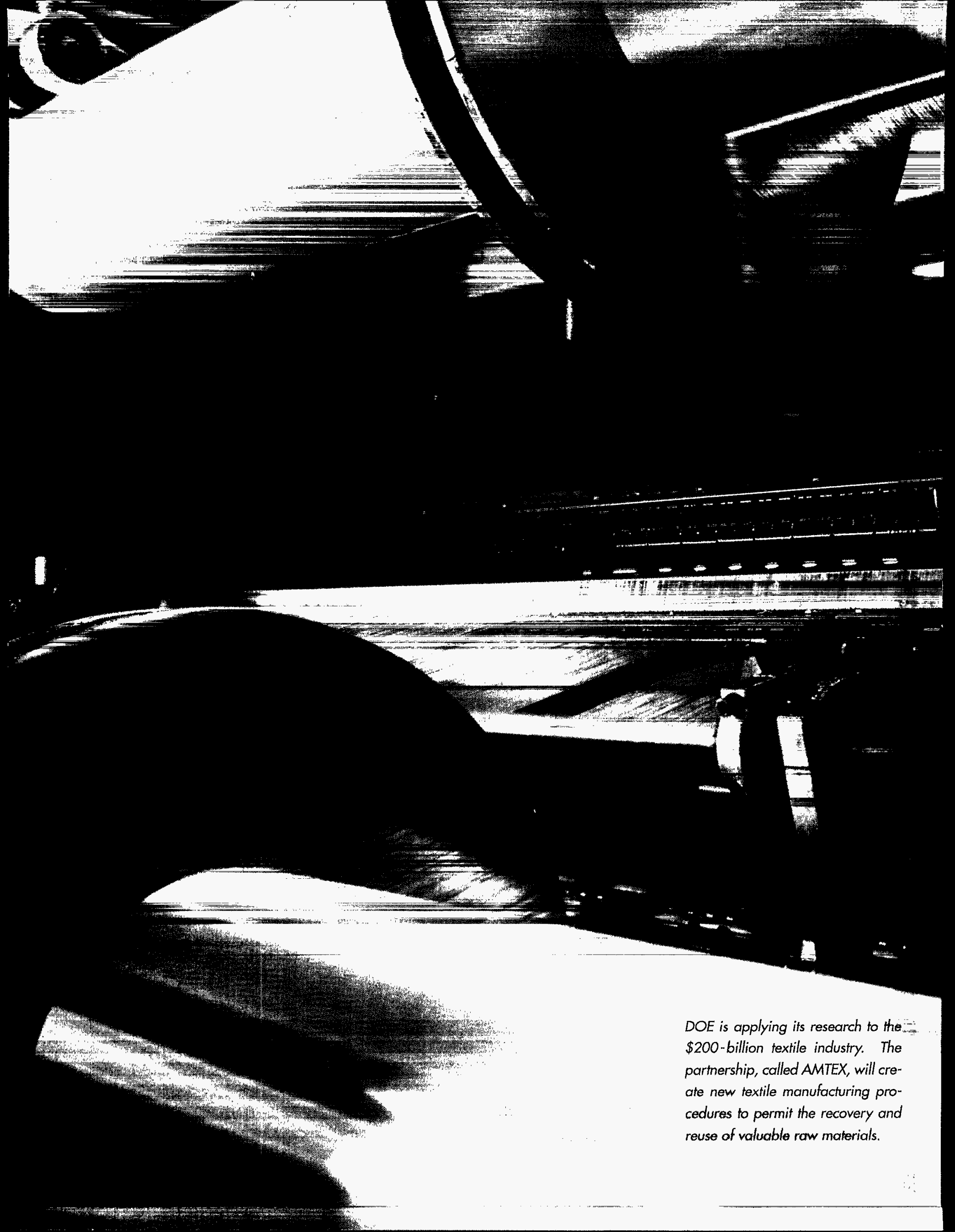
DoE's goal is to

develop new methods

of manufacturing

that are environmen-

tally benign and

energy efficient while

being economically

competitive with

existing practices. rom the smog-filled skies

that canopy so many of the world's major cities, to the industrial pollution that threatens the vitality of the nation's waterways, it is graphically evident that the Industrial Revolution has imposed a burden on the global ecosystem. Clean Manufacturing will only be achieved through a combination of new, economically viable environmental technologies and a wastefree "green" approach to manufacturing.

D A major thrust of DOE's environmental research is aimed at restoring and monitoring contaminated sites. This effort includes the development of physical, chemical, and biological processes for either removing or neutralizing toxic materials and hazardous waste products, and the development of advanced monitoring techniques that will allow quick and precise assessments of the cause and extent of environmental damage. The national laboratories also serve as a trouble-shooting test bed for the proposed remediation technologies of other federal agencies, universities, and private industry.
In too many cases, current manufacturing processes generate unwanted by-products that create problems for the environment. With their unique ability to solve problems through the use of multidisciplinary teams of scientists and engineers, the national laboratories are combining chemistry, physics, and state-of-theart techniques in lasers and robotics to redesign the worst of these manufacturing processes. The goal is to develop new methods of manufacturing that are product-specific, environmentally benign and energy efficient, while being economically competitive with existing practices. D A prime example of applying research to green manufacturing is an agreement between the $\$ 200$ billion American textile industry and eleven of DOE's national laboratories. Called the AMTEX partnership, it includes as a major component a

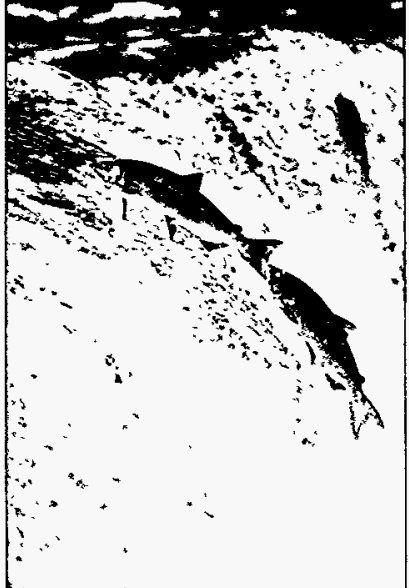

resource conservation project. The primary goal of this project-the largest environmental effort ever undertaken by the industry -is to create new textile manufacturing procedures that will permit the recovery and reuse of valuable raw materials. Success will not only be good for the environment, it will also strengthen the worldwide competitiveness of an industry that employs more than two million U.S. citizens.

D It has been estimated that the global market for environmental and related technologies will expand from a current $\$ 300$ billion level to more than $\$ 425$ billion within the next couple of years. Through scientific research and industrial partnerships, DOE is putting American companies in a position to continue their successful competition for this market for many years to come. 
Bs istix

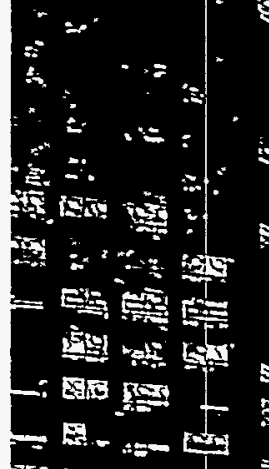
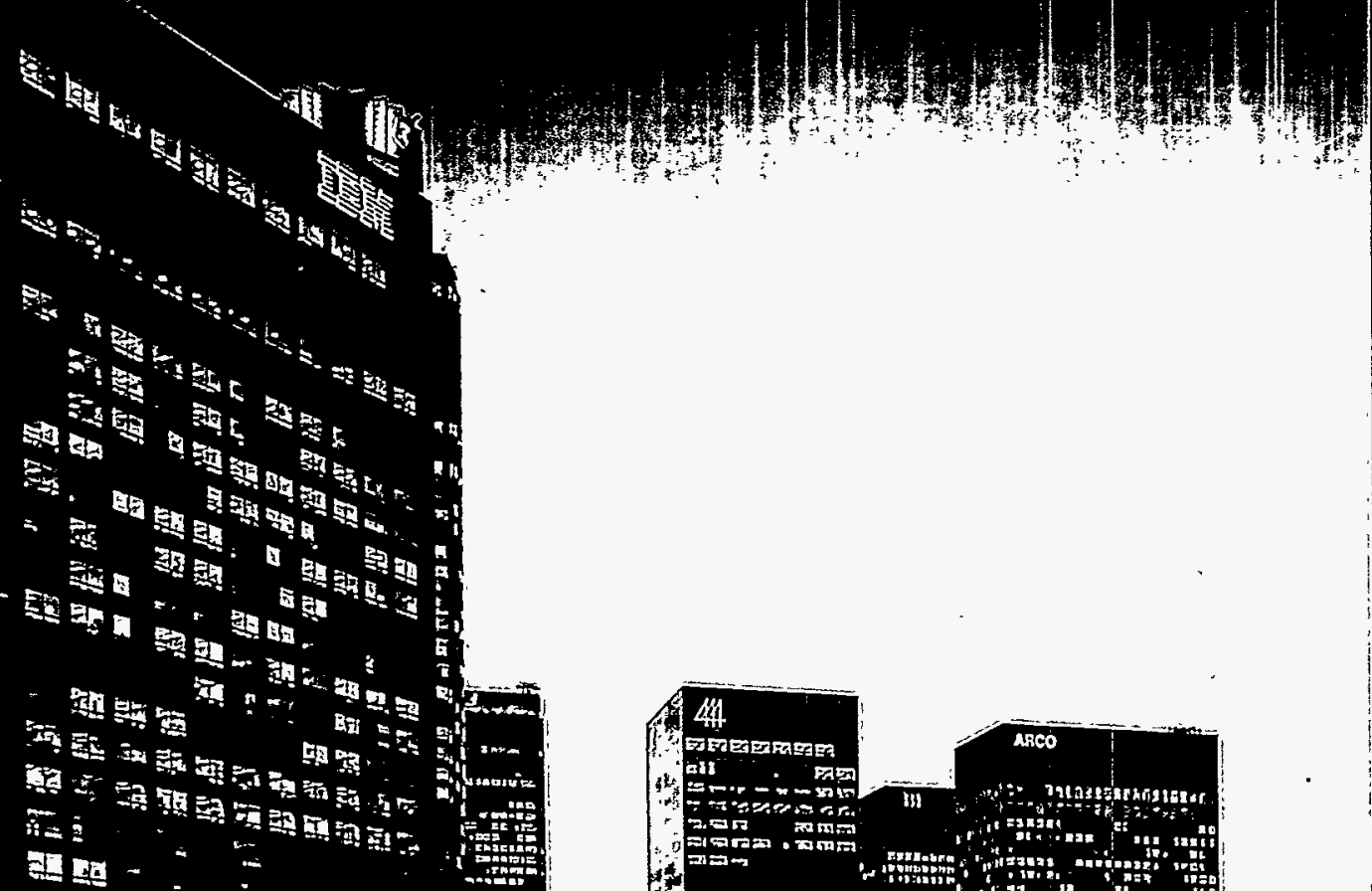

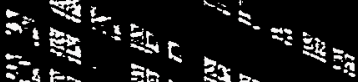

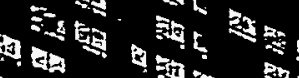

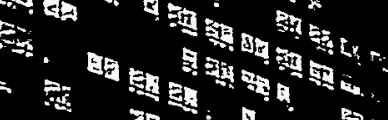
然日

팁.․․․

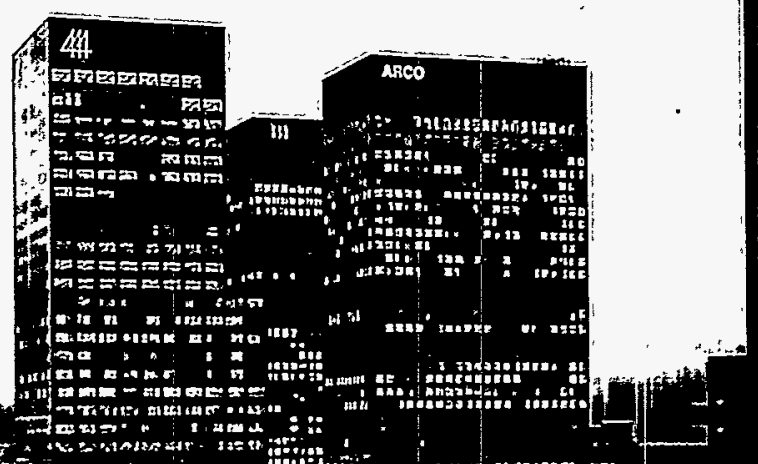

1FE:

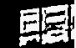

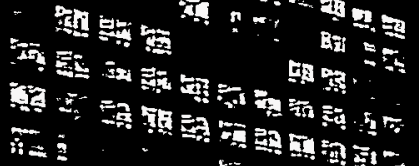

$\Rightarrow$ as

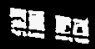

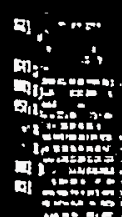

(1)

:

대료료

톨

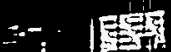

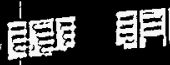

Fित्र

Ti"

त्व

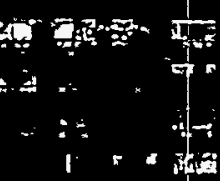

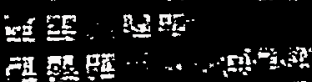

$\cos -2 \pi+2$

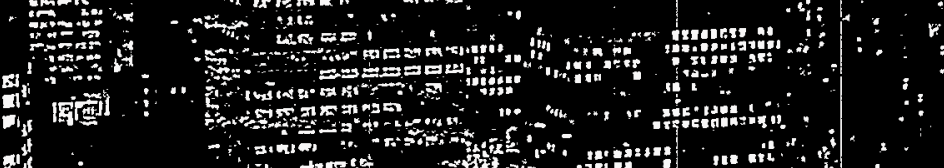

THIS PAGE: Los Angeles, like many major U.S. cities, relies on massive quantities of energy to keep itself running.

OPPOSITE, RIGHT: This infrared image demonstrates the dramatic temperature difference experienced by a person entering a vehicle parked in direct sun. DOE researchers are investigating dutomotive applications for energy efficient insulation and window glazings.

OPPOSITE, FARRIGHT: DOE'S Mulifiuel Combuster, a pilot-scale research facility, simulates com-

$\therefore$ bustion conditions within an industrial furnace or boiler, ollowing the resting of fuels such as natural gas, oil, pulverized coal, and solid or liquid biomass.

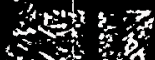
保。

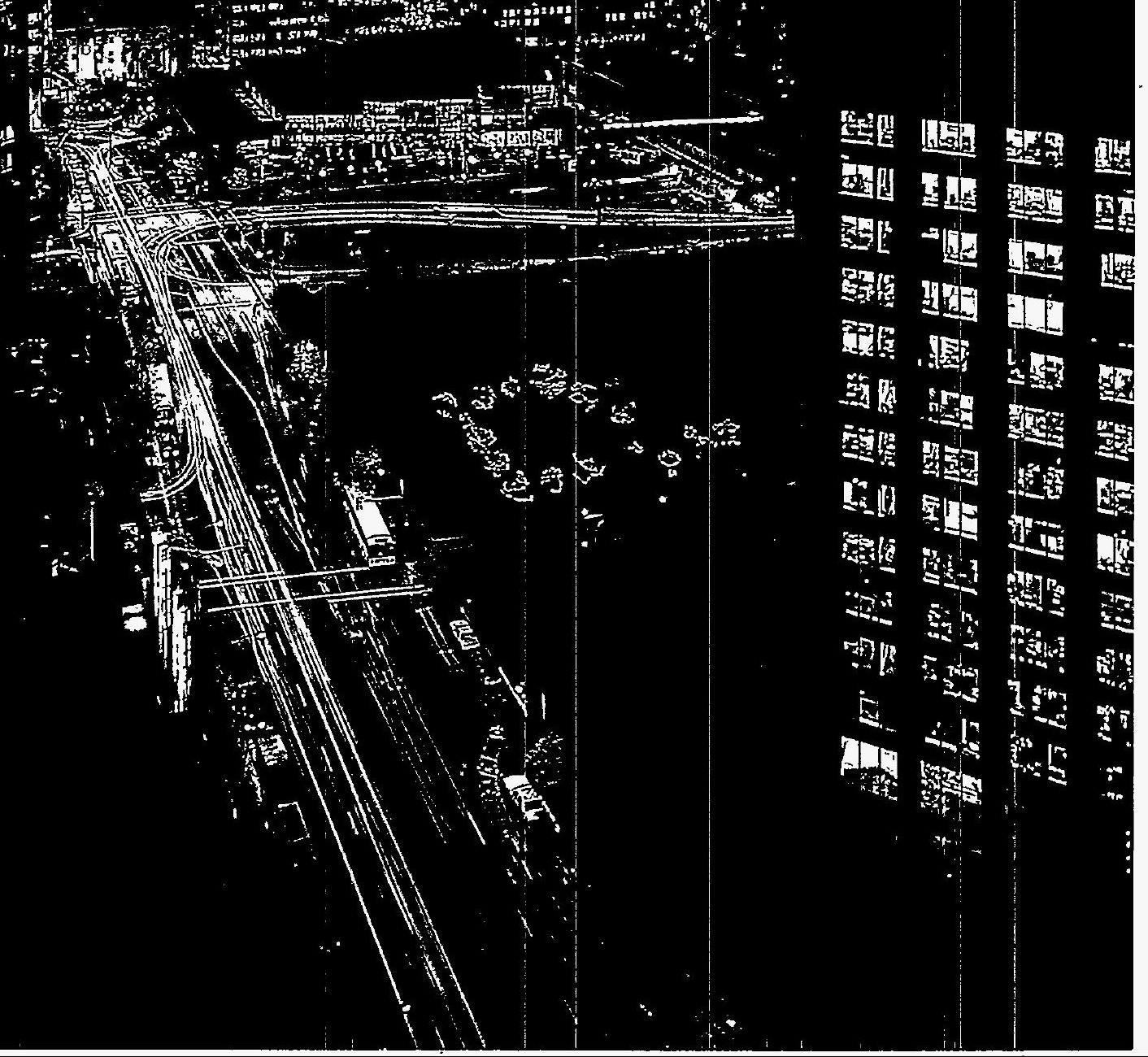


ENERGY EFFICIENCY

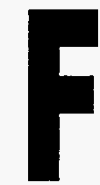

ossil fuels such as oil and coal provide us with 90 percent of the energy we consume; they will most likely continue to do so for a great many more years. Given the finite supply of this energy source, preservation through conservation is a necessity.

Dxtensive programs are

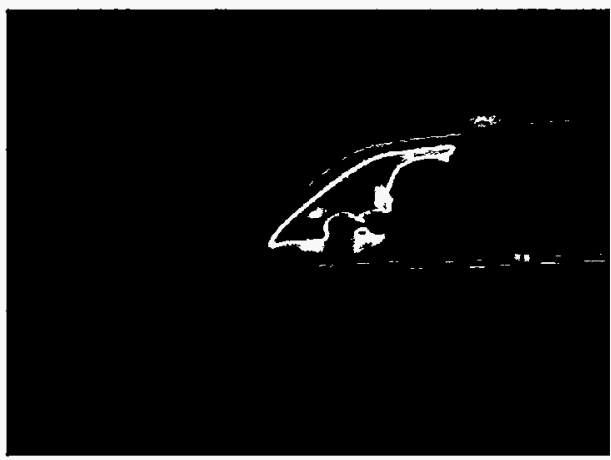

underway at the national laboratories to improve the efficiency with which fossil fuels are converted into energy in order

to make the most use of

Extensive programs

are underway at the

national laboratories

to improve the effi-

ciency with which

fossil fuels are con-

verted into energy. our resources. This research has primarily focused on understanding the basic chemistry of combustion, an extremely difficult task made possible only recently by new advances in laser and detector technologies at the labs. Better understanding should lead to better control over the process, which will nor only increase the efficiency by which energy is produced from fossil fuels, but will also serve to significantly cut back on pollutant emissions. In the area of con- servation, a multi-billion dollar industry in energyefficient technologies is now flourishing in this country as a direct result of DOE laboratory research programs on window coatings and other materials for insulation; and on lighting, heating and cooling systems for buildings and residences. DOE researchers are also developing improved methods of analysis that pinpoint where and how energy is being wasted, and computer modeling of architectural structures and designs that will reduce energy demands and stretch current resources to the maximum. Not only has the buildingbased conservation research of the national laboratories spawned a burgeoning new job and revenue-generating industry, it has held down the nation's energy bill an estimated $\$ 100$ billion below what it would otherwise have been.

- Another major conservation effort that should yield a substantial future payoff is a partnership between the national labs and the American automotive industry to develop a new generation of vehicles. These vehicles, which are to be commercialized dur- ing the next 10 to 20 years, should not only substantially boost the overall fuel-efficiency of the auto industry, they should also dramatically improve the quality of urban air. Specific projects already underway include the development of fuel cell systems for electricallypowered vehicles, a radical overhaul of gasoline-powered engine designs, the development of lightweight vehicle bodies and other structural components, and the creation of a national network of electronicallybased smart roads.

- Other opportunities for energy conservation being explored by DOE researchers include the development of an intelligent system for controlling electricity transmission and distributions, and the modification of existing technologies into an energysaving format that can benefit emerging nations.

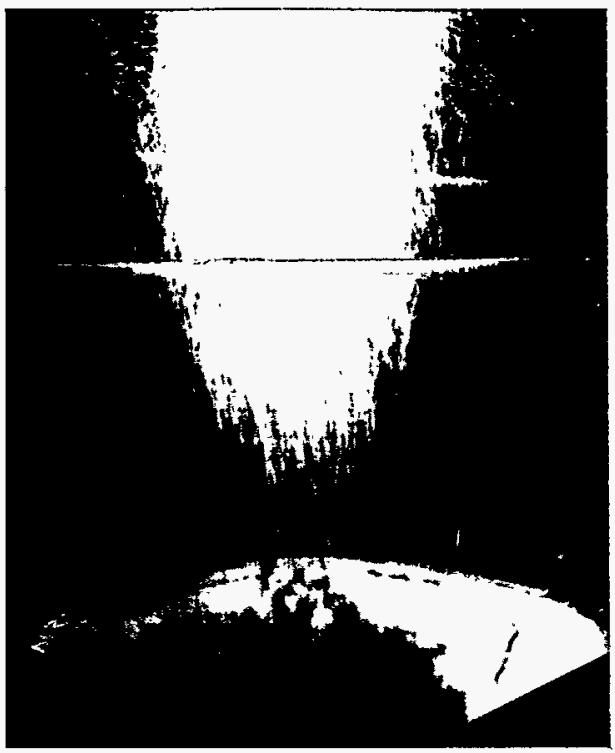




\section{RENEWABLE ENERGy SOURCES}

\section{Learning to control a}

fusion reaction so

that it could be safe-

ly used to generate

electricity would pro-

vide mankind with an

environmentally clean

supply of energy that

would last forever.

\section{$\mathbf{T}$}

he best way to conserve

something, of course, is to

not use it. To further

reduce the consumption of fossil fuels, scientists at the national laboratories are searching for alternative sources of energy that would be clean and renewable. For example, the supply of hydrogen on Earth is virtually inexhaustible and the consumption of hydrogen neither depletes the atmosphere's ozone level nor contributes to global warming. With the development of hydrogenbased energy technologies such as fuel cells, hydrogen could become as important as electricity for meeting our energy needs in the next century. Hydrogen fuel cells could be particularly valuable for replacing today's fossil-fuel powered modes of transportation with hydrogen-powered modes that would not only be better for the atmosphere, but would also be sustainable. National laboratory researchers are currently developing and testing all of the technologies required for a national shift to a hydrogen-powered transportation system.

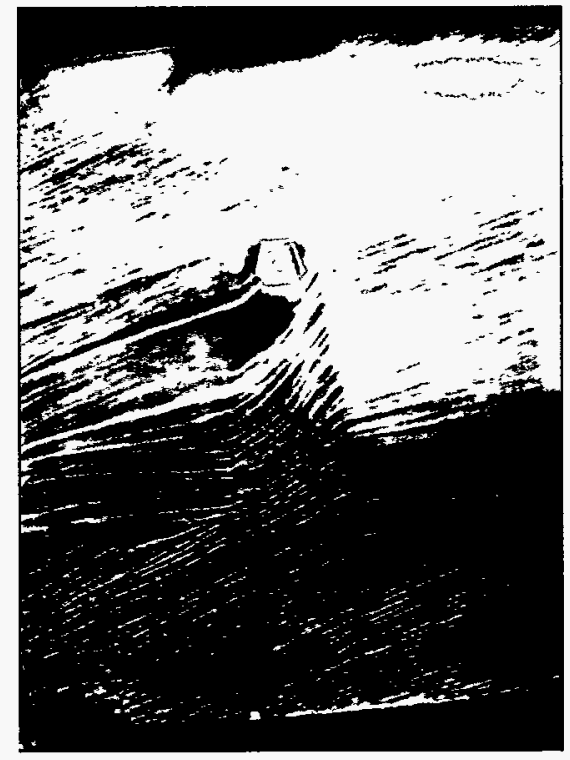

directly convert sunlight to electricity, and through the use of solarheat to create steam to drive electricity-generating turbines (called the solar-thermal

- Hydrogen is also the basis for what might prove to be the most pivitol energy technology of all - the harnessing of fusion power. Fusion, the melding together of lighter atomic nuclei to form heavier nuclei, is the source of energy for the sun. Learning to control a fusion reaction so that it could be safely used to generate electricity would provide mankind with an environmentally clean supply of energy that would last forever. Researchers at the national laboratories are exploring several different approaches to accomplishing this.

In addition to mimicking the source of the sun's energy, DOE laboratory scientists are also testing new ways of exploiting the solar energy that reaches Earth. Through the development of improved photo-voltaic cells that approach), researchers are overcoming the technological and economic barriers to solar power and making it more likely that predictions of a world dominated by solar energy production might one day come true. - There are also existing renewable energy sources whose technologies are investigated with the objective of making them more economically attractive. These include wind-driven turbines, geothermal and hydropower systems, and biomass - the generating of energy from agricultural and forest residues. Given that emissions from fossilfuel energy systems is the primary cause of concern about global climate changes, the national laboratories' research into renewable energy sources might be considered a disaster insurance policy for everyone. 


\section{DOE programs are}

applying computation-

al power to develop

global biodiversity

models that will help

us use our planet's

resources more wisely. rom a planetary perspective, the quality of life on Earth for our generation and for the generations to come hinges upon a tripod of clean air, clean water, and biodiversity. All are intertwined to create a whole that is truly greater than the sum of its parts.

A key to ensuring clean air and water is the design and creation of monitoring, modeling, and analysis systems that enable risk situations to be either detected or anticipated before they evolve into problems.

In the case of air quality, the greatest risks to human health are posed in urban areas, especially indoors where we spend most of our time. Remote sensing devices that can detect and track the activity of airborne chemicals, and computer-based models that can translate this data into projected trends are now in various stages of testing and development. These devices and models can be implemented on a local, regional, or even worldwide basis. Similar sensing devices and models are being applied to indoor air quality in combination with sensors that can immediately respond to potential problems by controlling ventilation and infiltration.

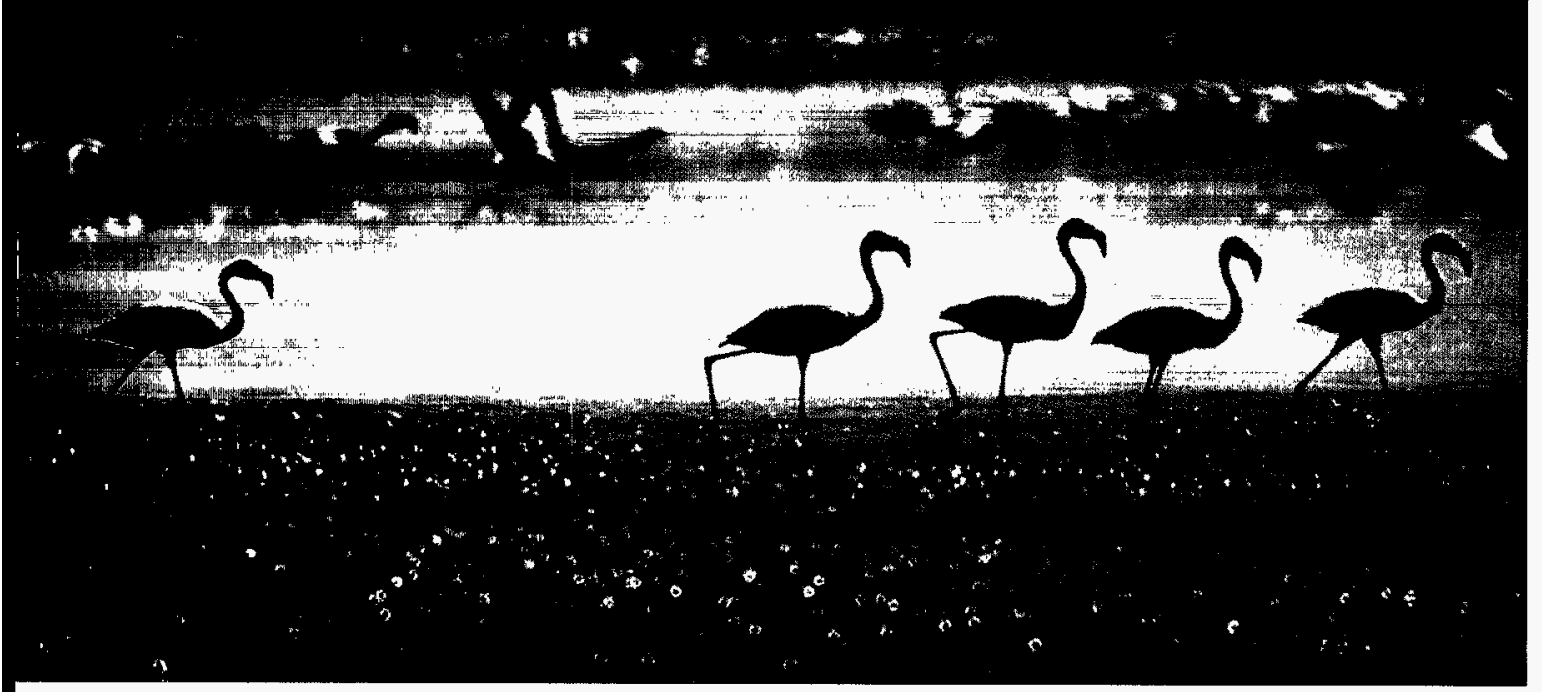




\section{AFTERWORD}

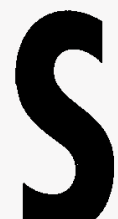

ustainable development holds the promise for a more prosperous and enduring future for all of us. The scientific enterprise of the Department of Energy's research programs promises to develop new technology, as well as to help us better understand our planet, more efficiently use our natural resources, and enhance our quality of life. DOE's science is focused on basic and applied research that provides the foundation for technical and economic advancement. By forming partnerships among universities, national laboratories, and industries across the nation, we are developing the most advanced instrumentation for understanding the world in which we live-from the atomic to the global scale. These technologies allow us to monitor our resources, to continue to develop our industrial processes, to eliminate hazardous waste, and to avoid the production of toxic substances. In this way, our research is ultimately directed to preserve our environment and to provide

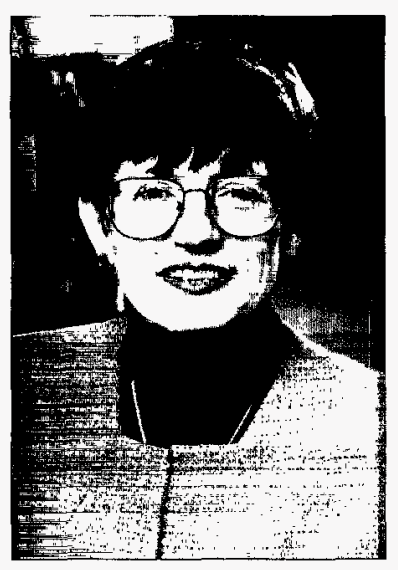
the basis for sustained economic growth. To make further advances we must continue to invest in national research programs, to forge partnerships, and to bring these skills and knowledge to bear in the global marketplace of products and ideas.
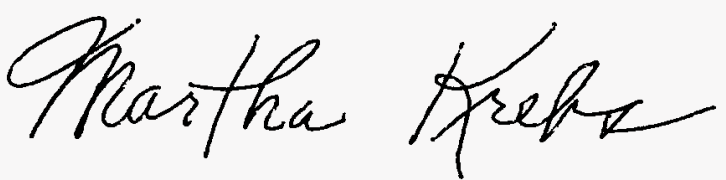

Martha Krebs

Director, Office of Energy Research 
